\title{
Effect of Different Dietary Regimes and Management Systems on Physiological Reactions and Feeding Behaviour of Sahiwal Calves
}

\author{
Vijay Kumar ${ }^{1^{*}}$, Vijay Kumar Chaudhary ${ }^{2}$, \\ Mohan Lal Chaudhary ${ }^{2}$ and Vikramjit Singh ${ }^{3}$
}

${ }^{1}$ Centre for Organic Animal Products Technology, Rajasthan University of Veterinary and Animal Sciences, Bikaner-334001, Rajasthan, India

${ }^{2}$ Department of Livestock Production and Management, College of Veterinary and Animal Science, Rajasthan University of Veterinary and Animal Sciences, Bikaner-334001, Rajasthan, India

*Corresponding author

\section{A B S T R A C T}

The present experiment was conducted on twenty four female Sahiwal calves of 4 to 8 months age. Calves were subjected to four treatment groups viz. 100 per cent of ICAR feeding and routine management $\left(\mathrm{T}_{1}\right), 100$ per cent of ICAR feeding and improved management $\left(T_{2}\right), 120$ per cent of ICAR feeding and routine management $\left(T_{3}\right)$ and 120 per cent of ICAR (Indian Council of Agricultural Research) feeding and improved management $\left(\mathrm{T}_{4}\right)$. The mean rectal temperature was $38.21 \pm 0.029,38.00 \pm 0.023,37.98 \pm$ 0.03 and $38.23 \pm 0.025^{\circ} \mathrm{C}$ in the morning and $38.89 \pm 0.027,38.94 \pm 0.030,39.15 \pm 0.020$ and $38.68 \pm 0.023{ }^{\circ} \mathrm{C}$ in the evening, the mean respiration rate was $25.50 \pm 0.070,25.61 \pm$ $0.076,25.50 \pm 0.047$ and $25.61 \pm 0.072$ per minute in the morning and $26.75 \pm 0.218$, $26.89 \pm 0.218,27.25 \pm 0.295$ and $26.39 \pm 0.080$ per minute in the evening and average pulse rate was $52.76 \pm 0.099,52.86 \pm 0.097,52.82 \pm 0.100$ and $52.80 \pm 0.096$ per minute in the morning and $53.91 \pm 0.153,53.98 \pm 0.162,54.91 \pm 0.139$ and $52.98 \pm 0.136$ per minute in the evening respectively for $T_{1}, T_{2}, T_{3}$ and $T_{4}$ group. The rectal temperature, respirations rate and pulse rate in evening were significantly $(\mathrm{P}<0.01)$ influenced by management systems. The time spent in rumination and resting was significantly influenced by the levels of feeding. The time spent by labourer for water splashing and care of calf per day were significantly $(P<0.01)$ influenced by levels of feeding as well as management system.

\section{Introduction}

Female calves are future herd of a dairy farm. They must be produced to replace the older and uneconomical females of the farm through voluntary culling. When genetic trends are positive, such replacements help harvest the benefits of genetic gain. Calf production is most expensive part of the dairy farm operation. It requires more inputs for a longer period of time with no visible returns than any other farm operation. Growth rates 
of replacement calf affect economic returns on dairy farms. Balanced feeding, improved management and minimum disease prevalence can be helpful in reducing the age at first calving.

Microclimate of the house has significant effect on the dry matter intake (DMI), milk yield and water intake of the animal. Lee et al., (1999) reported that daily feed intake increased by $2.79 \mathrm{~kg}$ in cooled cows compared with control cows. Patel et al., (1995) studied the effect of different housing patterns on feed and water intake in Mehsana buffalo heifers under semi arid conditions. The housing effect on feed intake was not significant, but monthly variations were significant. The total daily water intake was significantly different during different months.

Considering the tropical climate of Indian subcontinent, the summer stress is a major problem in managing dairy animals in India. During the extreme hot humid or hot dry weather, thermoregulatory capability of animals to dissipate heat by sweating and panting is compromised and Summer/heat stress occurs. Continued exposure to the direct sun results in loss of body water through evaporation resulting in dryness of skin, increased rectal temperature, respiration and pulse rates, off-feed and cessation of rumination leading to higher calf mortality, poor growth rate during summer (Hemsworth et al., 1995). Generally calves are housed in groups in confined outdoor yards during day that leave them exposed to episodes of high environmental temperatures, which can exceed their ability to dissipate body heat. The ensuing heat stress has important implications for cattle welfare as well as a negative impact on health and production; in extreme cases resulting in death. It has been observed that radiation energy flow on animal is $685 \mathrm{kcal} / \mathrm{m}^{2} \mathrm{~h}$, but actually only 340 $\mathrm{kcal} / \mathrm{m}^{2} \mathrm{~h}$ is from the direct solar radiation and rest is by reflected by floor, dust, wall, etc (Thomas and Sastry, 2007). Every year, loss in milk production due to heat stress causes huge financial loss in our country. Though indigenous breeds of cattle are more thermotolerant, crossbred and exotic breeds of cattle are highly sensitive to heat stress. Heat stress can be alleviated through housing management, making provision of cooling devices and nutritional management.

Hence, the present experimental design was planned to carry out the study on effect of Different Dietary Regimes and Management Systems on Physiological Reactions and Feeding Behaviour of Sahiwal Calves

\section{Materials and Methods}

\section{Animals and treatments}

Twenty four female Sahiwal calves between 4 to 8 months of age were selected from the herd of Sahiwal cattle breeding farm, Livestock Research Station Kodamdesar, RAJUVAS, Bikaner. These calves were divided into four groups of six calves each on the basis of nearness in their body weight and age. The particulars of these animals are given in table 1. The experimental groups were randomly allocated to one of the following treatments.

\section{Management systems}

\section{Routine management}

Routine management houses having covered area with coated tin shed roofing and concrete floor and open area with kachha floor, surrounded by four feet high fencing of galvanized iron pipes.

\section{Improved management}

Improved management in summer months having additional facilities of white painting 
over roof of tin sheds, feeding dry fodder in cool hour (i.e. 7:00 PM to 6:00 AM), prevention of calves from western hot wind (Loo, local wind) and water splashing twice daily than routine managements.

\section{Feeds and feeding}

All the experimental calves in each group were fed as per ICAR recommendations (ICAR, 1985). The calves were fed groundnut fodder and wheat straw during the experimental period. A concentrate mixture containing crushed wheat, groundnut cake and wheat bran was prepared. The ingredient composition of concentrate mixture along with its nutritive value is given in Table 2 . The concentrate mixture contained 21.50 per cent crude protein and 77.10 per cent of total digestible nutrients. The allowance of concentrate mixture was fixed in such a way that calves of treatment group $T_{3}$ and $T_{4}$ got 20 per cent higher levels of protein per head per day than calves of $T_{1}$ and $T_{2}$. A weighed amount of groundnut fodder was fed to all the calves daily and its protein content was taken into consideration while fixing the allowance of concentrate mixture for each group. The quantity of different feeds fed to each calf was adjusted at fortnightly intervals in order to meet the requirements of the calves with the change in their body weight.

\section{Physiological reactions}

Rectal temperature, respiration rate and pulse rate of all the calves were recorded at fortnightly interval in the morning (8:00 AM) and evening (6:00 PM) during the experiment. Rectal temperature was recorded by inserting clinical thermometer into the rectum for two minutes taking all precautions. Respiration rate was recorded by counting the movement of right flank (count per minute) of the animal. Pulse rate was recorded by palpating the coccygeal artery (count per minute)

\section{Behavioural studies}

Behavioural studies on calves under four different treatment groups were also conducted two times during the experiment i.e. at 3 months and at the end of experiment. The actual time spent by individual calf with respect to eating, rumination and resting were recorded over a twenty four hours period for day and night separately.

\section{Statistical analysis}

The experiment was planned and analyzed as 2 X 2 Factorial Randomized Block Design (Snedecor and Cochran, 1994). The differences among treatment means were tested for significance by performing Duncan's Multiple Range Test.

\section{Results and Discussion}

\section{Physiological reactions}

Despite the study of growth of Sahiwal calves under two levels of feeding and managements systems, it is important to make sure that 117 all the calves were under normal physiological conditions. The physiological response is the process of adjustment of the animal itself to other living material and to its external physical environment. Physiologists have used simple animal reactions like body temperature, respiration rate and pulse rate to assess animal reaction to environment and evaluate an animal's comfort.

Mean \pm SE values and effect of feeding levels and management systems on physiological parameters in morning (8PM) and evening (6PM) of each group of calves have been presented in Table 3 and their analysis of variance in Table 4.

\section{Rectal temperature}

The average morning rectal temperature in 
calves fed 100 per cent and 120 per cent of ICAR feeding were $38.21 \pm 0.024$ and $38.00 \pm 0.023 \quad{ }^{\circ} \mathrm{C}, \quad$ respectively. The corresponding values for evening rectal temperature were $38.89 \pm 0.027$ and $38.94 \pm 0.030 \quad{ }^{\circ} \mathrm{C}$. The average morning temperature in calves reared under routine management system and improved management were $37.98 \pm 0.033$ and $38.23 \pm 0.025^{\circ} \mathrm{C}$. The corresponding values for evening were $39.15 \pm 0.020$ and $38.68 \pm 0.023^{\circ} \mathrm{C}$, respectively. The mean rectal temperature of calves recorded in the morning was $38.20 \pm 0.029,38.22 \pm 0.09,37.76 \pm 0.024$ and $38.24 \pm 0.033^{\circ} \mathrm{C}$ and it was $39.10 \pm 0.029$, $38.69 \pm 0.034,39.21 \pm 0.028$ and $38.67 \pm 0.032^{\circ} \mathrm{C}$ in evening in T1, T2, T3 and T4 treatment groups, respectively. The evening rectal temperature was significantly lower $(\mathrm{P}<0.05)$ in calves reared under improved management system. It might be due to low ambient temperature in shed of improved management by the provision of ameliorative measures like white painting over the shad, twice water splashing daily and prevention of calves from direct western hot wind.

Analysis of variance of data on rectal temperature in the morning showed that there was no significant difference due to levels of feeding and management systems but evening rectal temperature was significantly influenced $(\mathrm{P}<0.05)$ by management systems. The interaction between the levels of feeding and management systems was found non significant.

Purwar et al., (2017) ${ }^{[}$reported that the overall mean value of afternoon rectal temperature was significantly $(\mathrm{P}<0.01)$ lower in the treatment group fed protected fat plus yeast, niacin, zinc, and chromium dietary supplementation on the reduction of heat stress in Karan Fries (KF) heifers during hot humid months.
The present finding are in agreement with Tucker et al., (2008) who concluded that cows provided with more protection $(99 \%$ shade) from solar radiation as compare to 50 per cent shade and no shade had lower rectal temperature with higher level of ambient solar radiation. Khongdee et al., (2010) found significantly lower mean rectal temperature $\left(38.56{ }^{\circ} \mathrm{C}\right)$ in shade cloth than that of the cows housed under normal roofing $\left(39.86^{\circ} \mathrm{C}\right)$. One has to consider also the normal diurnal variation in rectal temperature and other physiological reactions due to which the afternoon observations were higher than the morning ones. Alim and Ahmad (1957) observed such a diurnal variation in rectal temperature Egyptian buffaloes during summer. Thus it can be concluded that the behaviour of all the calves in various treatment groups was similar in this respect indicating their identical response to the microclimatic conditions to which they were exposed which was finally reflected in the rectal temperature pattern within physiological limits in the various groups.

\section{Respiration rate}

The average morning respiration rate in calves fed 100 per cent and 120 per cent of ICAR feeding were $25.50 \pm 0.070$ and $25.61 \pm 0.076$ count per minute, respectively. The corresponding values for evening respiration were $26.75 \pm 0.218$ and $26.89 \pm 0.218$ counts per minute. The average morning respiration rate in calves reared under routine management system and improved management were $25.50 \pm 0.047$ and $25.61 \pm 0.072$ count per minute, respectively. The corresponding values for evening respiration rate were $27.25 \pm 0.295$ and $26.39 \pm 0.080$ counts per minute. The mean values of respiration rate of calves recorded in the morning were $25.43 \pm 0.097,25.56 \pm 0.100$, $25.56 \pm 0.111$ and $25.66 \pm 0.104$ count per minute and it was $27.19 \pm 0.419,26.32 \pm 0.110$, 
$27.32 \pm 0.417$ and $26.47 \pm 0.116$ count per minute in evening in $\mathrm{T} 1, \mathrm{~T} 2, \mathrm{~T} 3$ and $\mathrm{T} 4$ treatment groups, respectively.

The evening respiration rate was significantly lower $(\mathrm{P}<0.05)$ in calves reared under improved management system. The higher levels of respiration rate in routinely managed calves in the evening indicated that these animals might have encountered relatively more thermal stress than the calves under improved management. The higher respiration rate in routinely managed calves might be attributed to more heat load which was get rid off by increased pulmonary evaporative cooling through respiratory channel.

Analysis of variance of data on respiration rate in the morning showed that there was no significant difference due to levels of feeding and management systems but evening respiration rate was significantly influenced $(\mathrm{P}<0.05)$ by management systems. The interaction between the levels of feeding and management systems was found non significant.

The present finding is similar to observation of Soley and Singh (2001) who reported higher respiration rate during afternoon than morning hours in crossbred calves during summer. Yazdani and Gupta (2005) observed higher $(\mathrm{P}<0.05)$ respiration counts in loose house as compared to those animals kept in thatch house. Khongdee et al., (2010), found significantly lower respiration rate in shade cloth than that of the cows housed under normal roofing. Schutz et al., (2010) reported increased respiration rate with increase in surrounding heat. The results of the present study is also supported by (Verma and Hussain, 1988; Bempong and Gupta, 1989; Verma et al., 1990; Kumar and Gupta, 1991; Sethi et al., 1994; Singh, 1996; Sirohi, 2003) who reported that the calves subjected to body wetting and cool hour feeding had significantly lower respiration rate.

\section{Pulse rate}

The average morning pulse rate in calves fed 100 per cent and 120 per cent of ICAR feeding were 52.76 \pm 0.099 and 52.86 \pm 0.097 count per minute, respectively. The corresponding values for evening pulse rate were $53.91 \pm 0.153$ and $53.98 \pm 0.162$ count per minute. The average morning pulse rate in calves reared under routine management systems and improved management were $52.82 \pm 0.100$ and $52.80 \pm 0.096$ count per minute, respectively. The corresponding values for evening pulse rate were $54.91 \pm 0.139$ and $52.98 \pm 0.136$ count per minute. The mean values of pulse rate of calves recorded in the morning were $52.74 \pm 0.144,52.79 \pm 0.136,52.91 \pm 0.141$ and $52.82 \pm 0.136$ count per minute and it was $54.87 \pm 0.193,52.96 \pm 0.182,54.94 \pm 0.203$ and $53.01 \pm 0.202$ count per minute in evening in treatment groups $\mathrm{T} 1, \mathrm{~T} 2, \mathrm{~T} 3$ and $\mathrm{T} 4$, respectively. The evening pulse rate was significantly lower $(\mathrm{P}<0.01)$ in calves reared under improved management system due to low ambient temperature in the improved management shed by adaption of heat ameliorative measures.

Analysis of variance of data on pulse rate in the morning showed that there was no significant difference due to levels of feeding and management systems but evening pulse rate was significantly influenced $(\mathrm{P}<0.01)$ by management systems. The interaction between the levels of feeding and management systems was found nonsignificant.

Similar results were obtained by Vijaya Kumar, (2005) observed significance $(\mathrm{P}<0.05)$ reduction in pulse rate in buffalo heifers subjected to cooling treatment than non cooled heifers at 2.00 PM. 


\section{Feeding behavior}

When livestock are introduced in a new environment, they show distinct changes in their behaviour relating to eating, rumination and resting. Although animals of a particular species have some common specific behavioural pattern yet several factors may influence variation in the same. Knowledge on feeding behaviour is of great importance for improving the management and production. In fact behaviour or rather changes in normal behaviour is an important means of adjusting to change in the environment to which animals are exposed.

Mean \pm SE values and effect of feeding levels and management systems on feeding behaviour during 24 hours have been presented in Table 5 and their analysis of variance in Table 6.

\section{Eating time}

The average values of time spent in eating in 100 per cent, 120 per cent of ICAR feeding, routine and improved management systems were $203.66 \pm 4.019,211.52 \pm 3.723,205.45$ \pm 3.941 and $202.65 \pm 3.945$ minutes per day, respectively. The corresponding values of time spent in eating by the calves were $201.08 \pm 5.849, \quad 206.25 \pm 5.674, \quad 209.81 \pm 5.726$ and 213.08 \pm 5.033 minutes per day in T1, T2, $\mathrm{T} 3$ and T4 treatment groups, respectively. The mean time spent in eating was higher in the calves fed higher level of nutrition and calves kept under routine management systems.

The analysis of variance revealed that time spent in eating was not significantly $(\mathrm{P}<0.05)$ influenced by levels of feeding and management systems. The interaction between the levels of feeding and management systems was found non- significant.

Similar results were obtained by Yazdani and Gupta (2005) who reported that the eating time recorded at monthly interval of crossbred calves shows no significant difference between thatch and loose house system. Maekawa (2002) reported that cow spent more time in eating when fed 40 per cent silage TMR than cows fed SI (243 vs. 198 min/day). Yazdani (1996) who observed non significant higher eating time in thatched roof house as compared to loose house in crossbred calves. The contrary results were found by Klinger et al., (2007) reported different type of feeding had significant effect $(\mathrm{P}<0.05)$ on eating time in cattle.

\section{Rumination time}

The average values of time spent in rumination in 100 per cent, 120 per cent ICAR feeding, routine and improved management systems were $435.16 \pm 2.436$, $444.47 \pm 2.071, \quad 437.20 \pm 2.453 \quad$ and $442.34 \pm 2.366$ minutes per day, respectively. The corresponding values of time spent in rumination by the calves were $431.58 \pm 3.367$, $438.75 \pm 3.339, \quad 442.63 \pm 3.107 \quad$ and $446.16 \pm 2.803$ minutes per day in T1, T2, T3 and T4 treatment groups, respectively. The time spent in rumination was slightly higher in calves reared under improved management systems and it was significantly higher $(\mathrm{P}<0.01)$ in calves fed 120 per cent of ICAR feeding in comparison to calves fed 100 per cent of ICAR feeding. This might be due to the fact that the animals fed higher plane of nutrition spent more time on feeding which in turn might have resulted in higher rumination time, although calves kept under improved management, spent slightly more time on rumination in comparison to routine management. 
Table.1 Feedings and managements of calves

\begin{tabular}{|c|c|}
\hline Treatments & Feedings and managements \\
\hline T1 & 100 per cent of ICAR feeding and routine management \\
\hline T2 & 100 per cent of ICAR feeding and improved management \\
\hline T3 & 120 per cent of ICAR feeding and routine management \\
\hline T4 & 120 per cent of ICAR feeding and improved management \\
\hline
\end{tabular}

Table.2 Percent ingredient composition of concentrate mixture used

\begin{tabular}{|l|c|}
\hline Ingredient & Proportion \\
\hline Wheat & $40 \%$ \\
\hline Wheat bran & $27 \%$ \\
\hline Groundnut cake & $30 \%$ \\
\hline Mineral mixture & $2 \%$ \\
\hline Common salt & $1 \%$ \\
\hline \multicolumn{2}{|c|}{ Nutrient Content on dry matter basis } \\
\hline Dry Matter & $90.79 \%$ \\
\hline Crude Protein & $21.50 \%$ \\
\hline Total Digestible Nutrients & $77.10 \%$ \\
\hline
\end{tabular}

Table.3 Mean \pm SE values and effect of feeding levels and management systems on physiological parameters

\begin{tabular}{|c|c|c|c|c|c|c|}
\hline \multirow[t]{2}{*}{ Variable } & \multicolumn{2}{|c|}{ Rectal temperature $\left({ }^{\circ} \mathrm{C}\right)$} & \multicolumn{2}{|c|}{$\begin{array}{c}\text { Respiration rate } \\
\text { ( per minutes) }\end{array}$} & \multicolumn{2}{|c|}{$\begin{array}{c}\text { Pulse rate } \\
\text { (per minutes) }\end{array}$} \\
\hline & Morning & Evening & Morning & Evening & Morning & Evening \\
\hline Feeding Level & NS & NS & NS & NS & NS & NS \\
\hline $100 \%$ ICAR (F1) & $38.21 \pm 0.024$ & $38.89 \pm 0.027$ & $25.50 \pm 0.070$ & $26.75 \pm 0.218$ & $52.76 \pm 0.099$ & $53.91 \pm 0.153$ \\
\hline $120 \%$ ICAR (F2) & $38.00 \pm 0.023$ & $38.94 \pm 0.030$ & $25.61 \pm 0.076$ & $26.89 \pm 0.218$ & $52.86 \pm 0.097$ & $53.98 \pm 0.162$ \\
\hline $\begin{array}{c}\text { Management } \\
\text { systems }\end{array}$ & NS & $\mathrm{S}^{*}$ & NS & $\mathrm{S}^{*}$ & NS & $\mathrm{S} * *$ \\
\hline $\begin{array}{c}\text { Routine } \\
\text { Management }\end{array}$ & $37.98 \pm 0.033$ & $39.15 \pm 0.020^{b}$ & $25.50 \pm 0.047$ & $27.25 \pm 0.295^{b}$ & $52.82 \pm 0.100$ & $54.91 \pm 0.139^{b}$ \\
\hline $\begin{array}{c}\text { Improved } \\
\text { Management }\end{array}$ & $38.23 \pm 0.025$ & $38.68 \pm 0.023^{\mathrm{a}}$ & $25.61 \pm 0.072$ & $26.39 \pm 0.080^{\mathrm{a}}$ & $52.80 \pm 0.096$ & $52.98 \pm 0.136^{\mathrm{a}}$ \\
\hline $\begin{array}{c}\text { Interaction } \\
\text { (FLXMS) }\end{array}$ & NS & NS & NS & NS & NS & NS \\
\hline T1 (F1M1) & $38.20 \pm 0.029$ & $39.10 \pm 0.029$ & $25.43 \pm 0.097$ & $27.19 \pm 0.419$ & $52.74 \pm 0.144$ & $54.87 \pm 0.193$ \\
\hline T2(F1M2) & $38.22 \pm 0.039$ & $38.69 \pm 0.034$ & $25.56 \pm 0.100$ & $26.32 \pm 0.110$ & $52.79 \pm 0.136$ & $52.96 \pm 0.182$ \\
\hline T3 (F2M1) & $37.76 \pm 0.024$ & $39.21 \pm 0.028$ & $25.56 \pm 0.111$ & $27.32 \pm 0.417$ & $52.91 \pm 0.141$ & $54.94 \pm 0.203$ \\
\hline T4 (F2M2) & $38.24 \pm 0.033$ & $38.67 \pm 0.032$ & $25.66 \pm 0.104$ & $26.47 \pm 0.116$ & $52.82 \pm 0.136$ & $53.01 \pm 0.202$ \\
\hline
\end{tabular}

Means with different superscripts differ significantly $(\mathrm{P}<0.05)$, highly significant $(\mathrm{P}<0.01)$ 
Table.4 Analysis of variance of data of physiological parameters

\begin{tabular}{|l|l|l|l|l|l|l|l|}
\hline \multirow{2}{*}{ Source } & \multirow{2}{*}{ d. f. } & \multicolumn{6}{|c|}{ Mean Sum of Square } \\
\cline { 3 - 8 } & & & $\begin{array}{r}\text { Rectal temperature } \\
\text { ('C) }\end{array}$ & \multicolumn{2}{c|}{$\begin{array}{c}\text { Respiration rate } \\
\text { (per minute) }\end{array}$} & \multicolumn{2}{c|}{$\begin{array}{c}\text { Pulse rate } \\
\text { (per minute) }\end{array}$} \\
\cline { 3 - 8 } & & Morning & Evening & Morning & Evening & Morning & Evening \\
\hline $\begin{array}{l}\text { Feeding } \\
\text { levels (FL) }\end{array}$ & 1 & 3.261571 & 0.161571 & 1.038462 & 1.551282 & 0.721154 & 0.320513 \\
\hline $\begin{array}{l}\text { Management } \\
\text { systems (MS) }\end{array}$ & 1 & 4.900032 & $17.31^{*}$ & 1.038462 & $57.55^{*}$ & 0.028846 & $288.46^{* *}$ \\
\hline FL x MS & 1 & 3.993878 & 0.340032 & 0.012821 & 0.012821 & 0.387821 & 0.012821 \\
\hline Error & 308 & 4.78235 & 0.075865 & 0.840493 & 7.336164 & 1.524184 & 2.988262 \\
\hline
\end{tabular}

* Significantly at $(\mathrm{P}<0.05), * *$ highly significant $(\mathrm{P}<0.01)$

Table.5 Mean \pm SE values and effect of feeding levels and management systems on feeding behavior

\begin{tabular}{|l|c|c|c|}
\hline Variable & $\begin{array}{c}\text { Eating time } \\
\text { (minutes per day) }\end{array}$ & $\begin{array}{c}\text { Rumination time } \\
\text { (minutes per day) }\end{array}$ & $\begin{array}{c}\text { Resting time } \\
\text { (minutes per } \\
\text { day) }\end{array}$ \\
\hline Feeding Level & $\mathrm{NS}$ & $\mathrm{S} * *$ & $\mathrm{~S}^{*}$ \\
\hline $\mathbf{1 0 0 \%}$ ICAR & $203.66 \pm 4.019$ & $435.16 \pm 2.436^{\mathrm{a}}$ & $800.87 \pm 4.631^{\mathrm{b}}$ \\
\hline $\mathbf{1 2 0 \%}$ ICAR & $211.52 \pm 3.723$ & $444.47 \pm 2.071^{\mathrm{b}}$ & $784.17 \pm 4.249^{\mathrm{a}}$ \\
\hline Management systems & $\mathrm{NS}$ & $\mathrm{NS}$ & $\mathrm{NS}$ \\
\hline Routine Management & $205.45 \pm 3.941$ & $437.20 \pm 2.453$ & $797.41 \pm 4.698$ \\
\hline Improved & $202.65 \pm 3.945$ & $442.34 \pm 2.366$ & $787.78 \pm 4.657$ \\
\hline Management & $\mathrm{NS}$ & $\mathrm{NS}$ & $\mathrm{NS}$ \\
\hline Interaction (FLXMS) & $201.08 \pm 5.849$ & $431.58 \pm 3.367$ & $807.33 \pm 6.316$ \\
\hline T1 (F1M1) & $206.25 \pm 5.674$ & $438.75 \pm 3.339$ & $794.41 \pm 6.497$ \\
\hline T2(F1M2) & $209.81 \pm 5.726$ & $442.63 \pm 3.107$ & $787.72 \pm 6.434$ \\
\hline T3 (F2M1) & $213.08 \pm 5.033$ & $446.16 \pm 2.808$ & $780.91 \pm 5.720$ \\
\hline T4 (F2M2) & & & \\
\hline
\end{tabular}

Means with different superscripts differ significantly $(\mathrm{P}<0.05)$, highly significant $(\mathrm{P}<0.01)$

Table.6 Analysis of variance of data on feeding behaviors

\begin{tabular}{|l|c|c|c|c|}
\hline \multicolumn{1}{|c|}{ Source } & d. f & \multicolumn{3}{c|}{ Mean Sum of Square } \\
\cline { 3 - 5 } & & $\begin{array}{c}\text { Eating time } \\
\text { (minutes per day) }\end{array}$ & $\begin{array}{c}\text { Rumination time } \\
\text { (minutes per day) }\end{array}$ & $\begin{array}{c}\text { Resting time } \\
\text { (minutes per ) }\end{array}$ \\
\hline Feeding levels (FL) & 1 & 724.6722 & $1018.33^{* *}$ & $3275.90^{*}$ \\
\hline Management systems (MS) & 1 & 206.569 & 310.2285 & 1090.083 \\
\hline FL x MS & 1 & 14.78381 & 69.46515 & 177.1641 \\
\hline Error & 43 & 365.3888 & 117.8925 & 458.4345 \\
\hline
\end{tabular}

* Significantly at $(\mathrm{P}<0.05), * *$ highly significant $(\mathrm{P}<0.01)$ 
The analysis of variance revealed that time spent in rumination was significantly $(\mathrm{P}<0.05)$ influenced by levels of feeding while it was not significantly affected by management systems. The interaction between the levels of feeding and management systems was found non significant.

Similar results were found by Klinger et al., (2007) reported different type of feeding had significant effect $(\mathrm{P}<0.05)$ on rumination time in cattle while Grewal (1980) observed that there was no significant difference in rumination time between two levels of concentrates. McCleod et al., (1994) ${ }^{[10]}$ observed that the time spent on rumination was not affected by feeding sequence of hay averaging 428 minutes and rumination tended to occur when there was no eating activity.

Maekawa (2002) reported that rumination time (546 min. per day) was similar in cow fed 40 per cent silage TMR and cows fed SI but rumination time increased from 498 to 516 and 584 minutes per day as silage in the TMR increased from 40 to 50, and then to 60 per cent, respectively.

\section{Resting time}

The average values of time spent in resting in 100 per cent, 120 per cent of ICAR feeding, routine and improved management systems were $\quad 800.87 \pm 4.631, \quad 784.17 \pm 4.249$, $797.41 \pm 4.698$ and $787.78 \pm 4.657$ minutes per day, respectively. The corresponding values of time spent in resting by the calves were $807.33 \pm 6.316, \quad 794.41 \pm 6.497, \quad 787.72 \pm 6.434$ and 780.91 \pm 5.720 minutes per day in $\mathrm{T} 1, \mathrm{~T} 2$, T3 and T4, treatment groups, respectively. The resting time was significantly higher $(\mathrm{P}<0.05)$ in calves fed 100 per cent of ICAR feeding in comparison to calves fed 120 per cent of ICAR feeding.
In conclusion, the present experiment was concluded that the mean evening rectal temperature, evening respirations rate and evening pulse rate were highly significant $(\mathrm{P}<0.01)$ influenced by management systems and the time spent in rumination and resting was significantly influenced by levels of feeding.

\section{Acknowledgement}

The authors thankfully acknowledge the financial support and facilities provided by RAJUVAS (Rajasthan University of Veterinary and Animal Sciences), Bikaner to carry out the research work.

\section{Conflict of Interest}

We declare that we have no conflict of interest.

\section{References}

Alim, K.A. and Ahmed, I.A. (1957). Studies on body temperature and respiration rate of buffalo cows under normal condition. Canadian Journal of Animal Science, 37: 130- 135.

Bempong, I.A. and Gupta, L.R. (1989). Effect of shelter and water sprinkling on the physiological reactions of crossbred cows during summer. Indian Journal of Animal Production Management, 5: 153.

Grewal, S.S. (1980). Effect of types of floor and levels of concentrate supplementation on growth rate in Murrah buffalo heifers. M. Sc. Thesis, submitted to Haryana Agriculture University, Hisar.

Hemsworth, P.H., Banetta, J.L., Beveridge, L. and Matthews, L.R. (1995). The welfare of extensively managed dairy cattle: a review. Applied Animal Behaviour Science, 42: 161- 182. 
ICAR. 1985. Nutrient requirements of livestock and poultry. Indian Council of Agricultural Research, New Delhi.

Khongdee, S., Sripoon, S., Chousawai, S., Hinch, G. and Chaiyabutr, N. (2010). The effect of modified roofing on the milk yield and reproductive performance of heat-stressed dairy cows under hot-humid conditions. Animal Science Journal, 81(5): 606-611.

Klinger, S.A., Block, H.C. and McKinnon, J.J. (2007). Nutrient digestibility, fecal output and eating behaviour for different cattle background feeding strategies. Canadian Journal of Animal Science, 87: 393-399.

Kumar, D. and Gupta, L.R. (1971). Effect of some summer managemental practices on the growth, physiological and biochemical responses of buffalo calves. Indian Journal of Animal Production and Management, 7: 98101.

Lee, S.N., Lieu, C., HSU, Y., Yang, T. and Chen, T. (1999). Sprinkling and force ventilation effects on physiological and reproductive responses of dairy cows during the hot season. Journal of Taiwan Livestock Research, 32(2): 13746.

Macleod, G.K., Colucci, P.E., Moore, A.D., Grieve, D.G. and Lewis, N. (1994). The effects of feeding frequency of concentrates and feeding sequence of hay on eating behavior, ruminal environment and milk production in dairy cows. Canadian Journal of Animal Science, 74(1): 103-113.

Maekawa, M., Beauchemin, K.A. and Christensen, D.A. (2002). Effect of concentrate level and feeding management on chewing activities, saliva production and ruminal $\mathrm{pH}$ of lactating dairy cows. Journal of Dairy Science, 85: 1165-1175.

Patel, J.B., Patel, J.P. and Pande, M.B.
(1995). Effect of Different Housing Patterns on Feed and Water Intake in Mehsana Buffalo under Semi-arid conditions. Indian Journal of Animal Science, 65: 88-90.

Purwar, V., Oberoi, P.S. and Dang, A.K. (2017). Effect of feed supplement and additives on stress mitigation in Karan Fries heifers. Veterinary World, 10(12): 1407-1412.

Schütz, K.E., Rogers, A.R., Poulouin, Y.A., Cox, N.R. and Tucker, C.B. (2010). The amount of shade influences the behaviour and physiology of dairy cattle. Journal of Dairy Science, 93:125-233.

Sethi, R.K., Bharadwaj, A.and Chopra, S.C. (1994). Effect of heat stress on buffaloes under different shelter strategies. Indian Journal of Animal Science, 64: 1282-1285.

Singh, M.P. 1982. Effect of different housing conditions during summer and winter season on feed utilization and water intake by growing buffalo calves. $\mathrm{Ph} \mathrm{D}$. Thesis, submitted to Haryana Agricultural University, Hisar.

Singh, R.K., Verma, D.N. and Verma, A.K. (1996). Influence of levels of dietary protein on feed intake and nutrient utilization in buffalo heifers. Indian Journal of Animal Nutrition, 13(3): 148151.

Sirohi, R. (2003). Effect of summer management practices on performance of buffalo heifers. M.V.Sc. Thesis, submitted to CCS Haryana Agricultural University, Hisar.

Snedecor, F.W. and Cochran, W.G. (1994). Stastical Methods (8th ed.). Oxford and IBH Publishing Co., Calcutta.

Soley, M.J. and Singh, S.V. (2001). Physiological and haematological responses of crossbred males under different housing conditions. M.Sc. Thesis, submitted to Dairy Science 
College, National Dairy Research Institute, Karnal, Haryana.

Thomas, C.K. and Sastry, N.S.R. (2007). Problems of Dairy production in Hot Regions. Dairy Bovine Production. 1st edition, Kalyani Publisher, Ludhiana. P. 111.

Tucker, C.B., Rogers, A.R. and Schütz, K.E. (2008). Effect of solar radiation on dairy cattle behaviour, use of shade and body temperature in a pasture-based system. Applied Animal Behaviour Science, 109: 141-154.

Verma D.N., Hussain, K.Q. and Bharat, R. (1990). Effect of water application on the body surface of buffaloes on body temperatures, pluse, respiration and milk during summer season. Indian Veterinary Medicine Journal, 14: 119.

Verma, D.N. and Hussain K.Q. (1988). Effect of shower on physiological parameters,
Nutrient utilization and milk production in buffaloes. Proc. II world Buffalo Congress, New Delhi. P. 323.

Vijayakumar, P. (2005). Effect of thermal stress management on nutritional, physiological and behavioural responses of buffalo heifers. "Ph.D. Thesis" submitted to Deemed University, IVRI, Izatnagar, Bareilly (U.P.) India.

Yazdani, A.R. (1996). Effect of the different source of proteins and type of housing on the growth performance of crossbred calves. Ph. D Thesis, submitted to CCS, Haryana Agricultural University, Hisar.

Yazdani, A.R. and Gupta, L.R. (2005). Effect of Housing and feeding system on Feed Utilization and Physiological Responses in Crossbred Calves. Indian Journal of Dairy Science, 53: 88-92.

\section{How to cite this article:}

Vijay Kumar, Vijay Kumar Chaudhary, Mohan Lal Chaudhary and Vikramjit Singh. 2021. Effect of Different Dietary Regimes and Management Systems on Physiological Reactions and Feeding Behaviour of Sahiwal Calves. Int.J.Curr.Microbiol.App.Sci. 10(01): 1173-1183. doi: https://doi.org/10.20546/ijcmas.2021.1001.141 